\title{
Insecticidal effects on pollinator's population and pollen mediated gene flow from transgenic to non-transgenic cotton genotypes
}

Saeed Ahmad ${ }^{1}$, Saghir Ahmad ${ }^{1}$, Zia Ullah Zia ${ }^{1 *}$, Muhammad Rafiq Shahid ${ }^{1}$, Abdul Latif Tipu ${ }^{1}$, Wajid Nazeer ${ }^{1}$, Abdul Jabbar ${ }^{1}$, Ghayour Ahmad $^{1}$, Muhammad Attiq Sadiq ${ }^{1}$, Muhammad Shahid ${ }^{1}$, Muhammad Akram $^{1}$ and Muhammad Asif Saleem ${ }^{2}$

1. Cotton Research Institute Multan-Pakistan

2. Department of Plant Breeding \& Genetics, Bahauddin Zakaryia University Multan-Pakistan

*Corresponding author's email: zia_pbg@yahoo.com

Citation

Saeed Ahmad, Saghir Ahmad, Zia Ullah Zia, Muhammad Rafiq Shahid, Abdul Latif Tipu, Wajid Nazeer, Abdul Jabbar, Ghayour Ahmad, Muhammad Attiq Sadiq, Muhammad Shahid, Muhammad Akram and Muhammad Asif Saleem. Insecticidal effects on pollinator's population and pollen mediated gene flow from transgenic to nontransgenic cotton genotypes. Pure and Applied Biology. Vol. 9, Issue 4, pp2182-2189. http://dx.doi.org/10.19045/bspab.2020.90233

Received: 19/03/2020 Revised: 30/05/2020 Accepted: $12 / 06 / 2020$

Online First: 29/06/2020

\section{Abstract}

Effectiveness of refuge crop is on risk due to shifting of pollen mediated gene flow by honey bee pollinators. Pesticides and pollinators both are essential for the high and quality production of many crops. Present studies were therefore carried out to study the pesticide risks on pollinators and the ultimate effect of pollinators on cotton refuge crop. Pollinator population was badly affected in insecticide treated plots with 92 percent reduction over control. Honey bee were the efficient pollinator in cotton and pollen mediated gene flow was recorded as higher as up to 26 percent in absence of any chemical or toxic sprays. Among cultivars VH-290 showed the highest attraction for honeybees and consequently greater gene flow (21.2\%) than other varieties because of its unique floral morphology. Regression analysis of pollinator population per plant and gene flow demonstrated that one-unit increase in pollinator population would increase geneflow @ $6.86 \%$ in sprayed field and $7.09 \%$ in un sprayed field. It is concluded that we should cultivate refuge non Bt cotton that have minimum chance of gene flow in order to minimize pollen mixing, maintain the quality of the refuge crop and to counter the field evolved resistance of insect pests against pesticides.

Keywords: Honey bee; Pollen mediated gene flow; Pesticide risk; Pollinator; Refuge crop

\section{Introduction}

Cotton is economically most important cash crop of Pakistan. It faces a large number of biotic and abiotic stresses from the seedling to the harvest stage. Among biotic stresses lepidopteron insect pests are of immense significance which require maximum doses of pesticides for the management of insect 
pests [1]. Due to lack of knowledge about the economic threshold and the identification of insect pests and predators, farmers follow calendar spray schedule for the management of these insect pests [1]. As a result nontarget species are unintentionally affected from the harmful effect of pesticides $[2,3]$. Some major reasons for the mortality of nontarget fauna could include; direct exposure of pesticides, the toxic effect due to spray drift or ingestion of prey/ nectar treated with pesticides [4].

The introduction of $\mathrm{Bt}$ cotton has the most outstanding characteristic of crystalline protein for the management of lepidopteran larvae. This technology has been accepted all over the world. Since 2006-17, the range of Bt crops planted has increased from 1.7 to 189.8 million hectares [5]. It not only has reduced the number of sprays against $H$. armigera but also promoted the pollinator fauna. Honey bees are important cotton pollinators that visit the flowers of the same plant or randomly the flowers of several other plants. One-third of the crops are insectpollinated [6] and of the total insect pollinating agents $80 \%$ share is of honey bees [7].

Other than having positive effects on pollination and crop productivity, honeybees are also responsible for pollen mediated gene flow from GM cotton to non-GM cotton. This gene flow could contaminate the non $\mathrm{Bt}$ refuge crop. Refuge crops (non-Bt) along with Bt crops are very useful to delay field evolved resistance and have increased the effectiveness of transgenic crops [8]. This gene flow may also affect the seed production practices and biodiversity.

In this study was examined the potential risks of insecticide on pollinator/honey bee population on four different genotypes, the role of floral morphology in pollinator attraction and pollen mediated gene flow from $\mathrm{Bt}$ to non $\mathrm{Bt}$ genotypes under insecticide and non-insecticide regimes.
In this study was examined the potential risks of insecticide on pollinator/honey bee population at four different genotypes. This experiment was conducted in field condition in two different blocks. Various, flower related, quantitative and qualitative traits of all the four genotypes were studied to investigate the role of floral morphology in pollinator attraction. Under the influence of pollinator/honey bee, the pollen mediated gene flow from Bt to non Bt genotypes was also studied in insecticide sprayed and nonsprayed field for the effectiveness of refugia crop.

\section{Materials and methods}

Pollen mediated gene flow in cotton through honey bee pollinators was observed at Cotton Research Station Vehari during 2017-18. Study was carried out both under field and green house conditions.

\section{Plant material}

Plant material comprised off one Bt. (MNH886) and four non Bt. genotypes i.e., VH281, VH-289, VH-290 and MNH-786. Cultivated variety MNH-786 and MNH-886 were collected from Cotton Research Institute Multan whereas all the other genotypes were collected from Cotton Research Station Vehari, keeping seed purity in consideration.

\section{Field study}

Experiment was divided into treated and untreated plots on the basis of plant protection measures. In treated plot, pesticides required for the management of both sucking and chewing insect pests were applied but in un-treated plot there was no application of pesticide, Sowing was accomplished in the first week of May 2016 at the experimental area of Cotton Research Station, Vehari. Seeds of non Bt genotypes were grown in the field in such a way that each non Bt. genotype was sandwiched between two rows of Bt. cultivar MNH-886 to ensure maximum chance of gene flow from transgenic cotton to non-transgenic 
cotton. The plant to plant and row to row distance was maintained at $30 \mathrm{~cm}$ and $75 \mathrm{~cm}$ respectively. All the standard agronomic and cultural practices were followed. At maturity crop was harvested and seeds were stored separately for further evaluation in the green house.

\section{Pollinator activity}

Pollinators visit activity was observed on tested cultivars at 8:00 am because during morning time there was presence of white flowers and maximum activity of pollinators was observed on fortnight basis throughout the season. Dipterous flies and wasps were keenly observed many times in the field, they were found feeding on nectary honey dews and honey bees were the only pollinators that visited many white flowers. Total number of bees were divided by total number of flowers observed during different observation dates as reported by McGregor (1959). Honey bees were the major source of pollen mediated gene flow in cotton which were counted on five randomly selected plants of each genotype.

\section{Green house study}

In October 2016, a total of 400 healthy and vigorous seeds of each genotype were sorted from the open pollinated seeds collected from the field and sown in earthen pots in green house (Fig. 1). Kanamycin solution @2\% was applied on fully mature leaves for the identification of $\mathrm{Bt}$ and non Bt plants. Plants expressing brown spots were considered nontransgenic, while rest were considered transgenic.

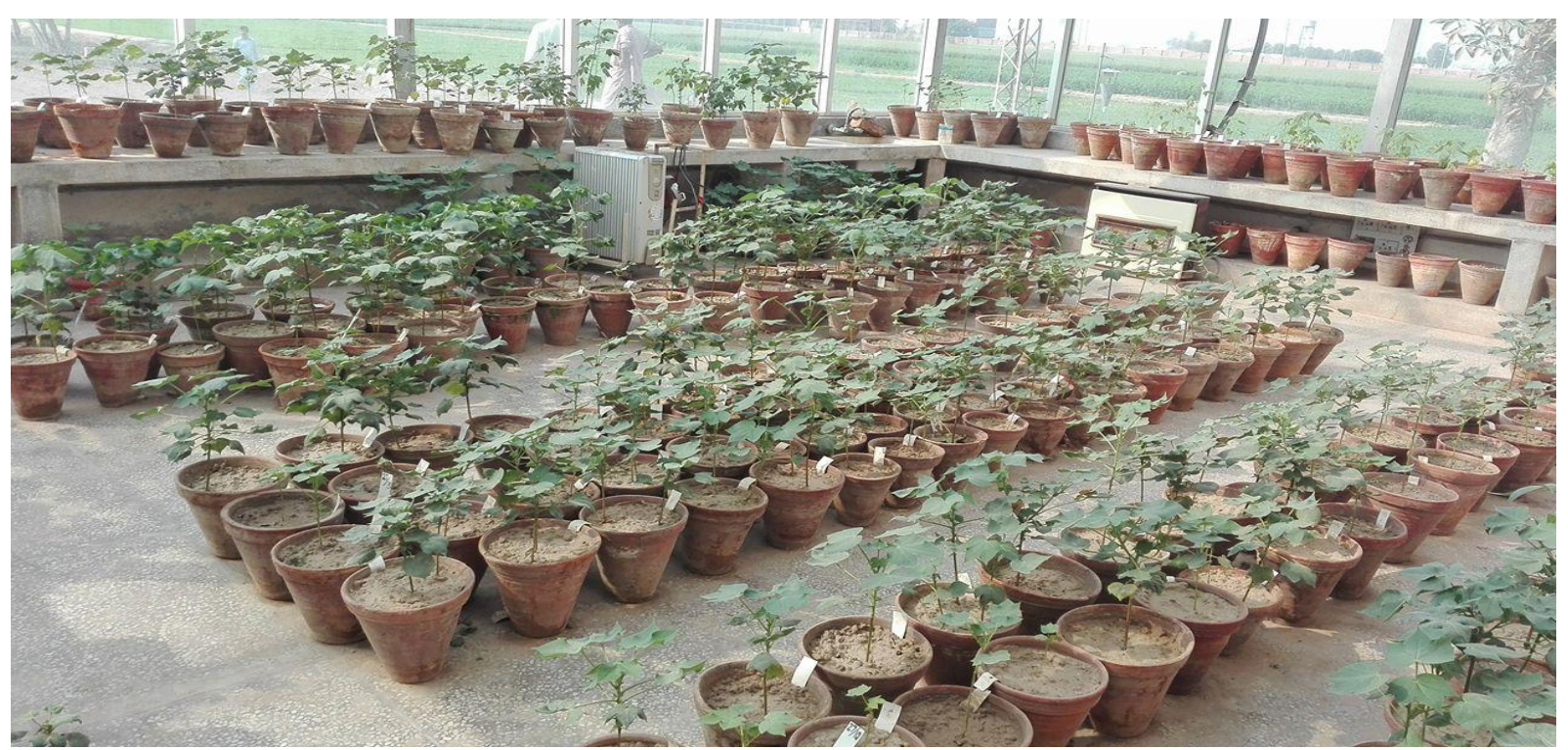

Figure 1. Transgenic plants in green house after kanamycin application

\section{Statistical analysis}

Pollinator population in treated and untreated plot as well as among cultivars were compared by using Tuckey Honesty Test. Analysis of variance was used to determine the level of significance at $\alpha$ (0.05).
Correlation and regression analysis was computed to find out the association and dependence of pollen mediated gene flow on the pollinator population. Percentage gene flow was calculated by using following formula;

$$
\% \text { gene flow }=\frac{\text { number of } B t \text { plants }}{\text { total number of plants }} \times 100
$$


Statistical analysis was conducted by using statistical Package R-studio 3.5.0 version.

\section{Results}

Pollinator response and gene flow in nonsprayed field

Cotton is an often-cross pollinated crop which solely depends on pollinator population particularly honey bees for movement of pollens from one cultivar/genotype/plant to other. The results (Table 1) for per plant pollinator (honey bees) population and percent gene flow showed that the highest pollinator population was recorded on VH-290 (2.6/plant) followed by VH-289 (2.3/plant), VH-281 (1.5/plant) and
MNH-786 (1.3/plant) in unsprayed field (Fig. $2 \& 3)$. The results for percent gene flow were compatible with that of pollinator population. The highest geneflow was recorded for $\mathrm{VH}-$ $290(26 \%)$ followed by VH-289 (21\%), VH281 (18.3\%) and MNH-786 (15\%) under non-sprayed conditions.

In pesticide untreated field regression model $(\hat{y}=6.44+7.09 x)$ demonstrated that in absence of pollinators gene flow was $6.44 \%$ and one unit increase in pollinator population may increase gene flow upto $7.09 \%$.

Table 1. Summary of regression coefficient for non-sprayed field

\begin{tabular}{|c|c|c|c|c|}
\hline Variable & Estimate & Std. Err & t Value & $\operatorname{Pr}(>|\mathbf{t}|)$ \\
\hline Intercept & 6.44 & 3.27 & 1.97 & 0.1881 \\
\hline Pollinators.plant.un.sprayed & 7.09 & 1.64 & 4.33 & 0.0494 \\
\hline
\end{tabular}

Pollinator response and gene flow in insecticide sprayed field

Insecticide used of the control of various insects pests were found to have a significant impact on both pollinator population and pollen mediated gene flow between the genotypes. The results (Table 2) showed that the highest per plant population of pollinators was recorded on $\mathrm{VH}-290$ (1.8) followed by VH-281 (1.4), VH-289 (0.6) and MNH-786 (0.3) in insecticide sprayed field (Fig. 4). Similar kind of trend was also recorded for percent gene flow. The highest gene flow through pollination was observed for $\mathrm{VH}-290$ (16.3\%) followed by VH-281 (13.7\%), VH$289(7.7 \%)$ and MNH-786 (6.3\%) as shown in (Fig. 5).

Regression fitted model $(\hat{y}=3.97+6.86 x)$ demonstrated that without pollinators, gene flow in sprayed cotton field was $3.97 \%$, one unit increase in pollinator could increase gene flow up to 6.86 percent. The model was best fitted because mean (6.86) were three times greater than standard error (0.287). A significant effect of pollinator in gene flow of cotton was observed (Table 2).

Table 2. Summary of regression coefficient for sprayed field

\begin{tabular}{|c|c|c|c|c|}
\hline Variable & Estimate & Std. Err & t Value & $\operatorname{Pr}(>|\mathbf{t}|)$ \\
\hline Intercept & 3.97 & 0.3416 & 11.62 & 0.0073 \\
\hline Pollinators.plant.sprayed & 6.86 & 0.2874 & 23.87 & 0.0018 \\
\hline
\end{tabular}

Pollinator response towards floral
morphology

VH-290 attracted the highest number of pollinators (2.2/plant) and showed maximum geneflow $(21.2 \%)$. This cultivar had large flowers with 6 petal, yellow pollen and long protruded stigma, whereas all the other cultivars had medium sized flowers with 4 
petal, creamy pollen color and medium sigma length (Table 3 ).

Table 3. Floral morphology of the four selected genotypes

\begin{tabular}{|c|c|c|c|c|c|c|}
\hline Cultivar & Flower size & $\begin{array}{c}\text { No. of } \\
\text { Petals }\end{array}$ & $\begin{array}{c}\text { Pollen } \\
\text { Color }\end{array}$ & Stigma Size & $\begin{array}{c}\text { Average } \\
\text { Pollinator/ } \\
\text { plant }\end{array}$ & $\begin{array}{c}\text { Average } \\
\text { Gene flow } \\
(\%)\end{array}$ \\
\hline VH-281 & Medium & 5 & Creamy & Medium & 1.5 & 16.0 \\
\hline VH-290 & Large & 6 & Yellow & Long & 2.2 & 21.2 \\
\hline VH-289 & Medium & 5 & Creamy & Medium & 1.5 & 14.4 \\
\hline MNH-786 & Medium & 5 & Creamy & Medium & 0.8 & 10.7 \\
\hline
\end{tabular}
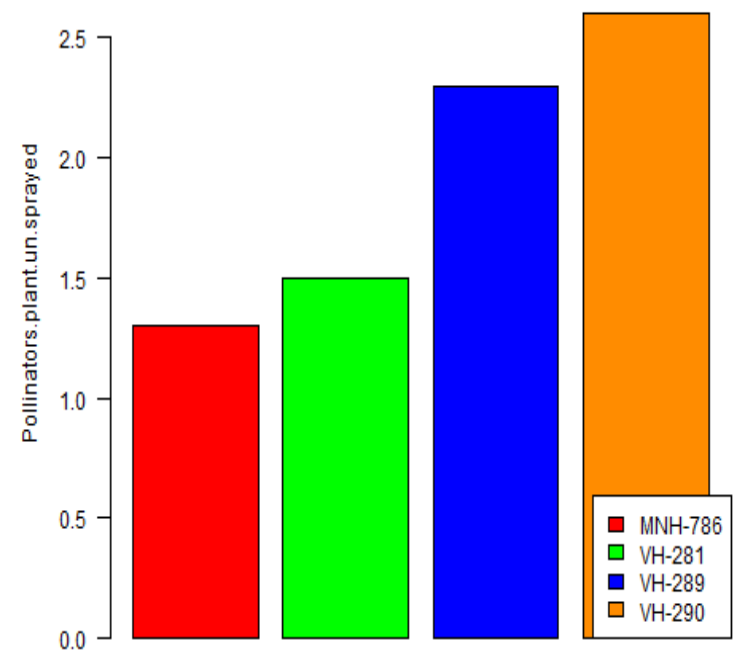

Figure 2. Pollinators' response against genotypes in unsprayed field

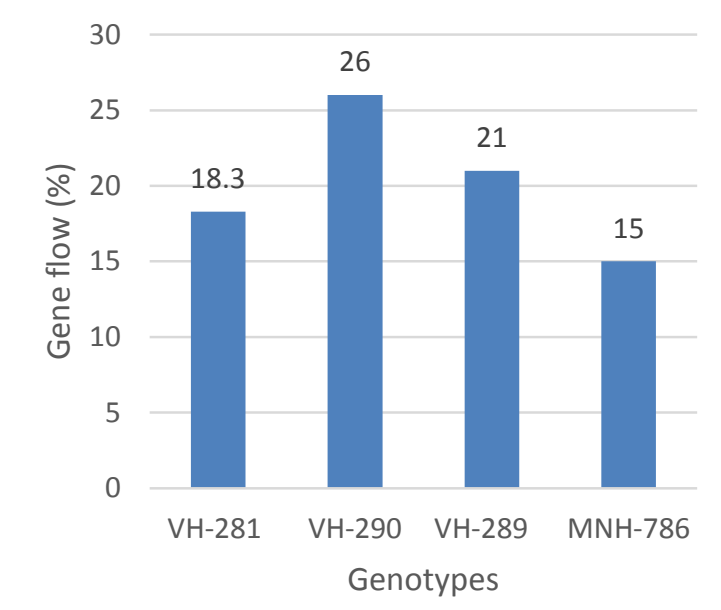

Figure 3. Percent gene flow in various genotypes in unsprayed field 


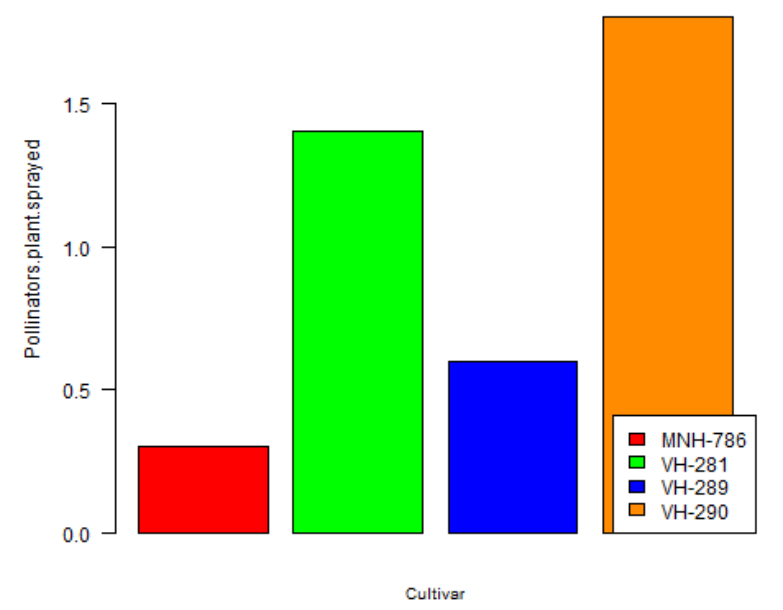

Figure 4. Pollinators' response against genotypes in insecticide sprayed field

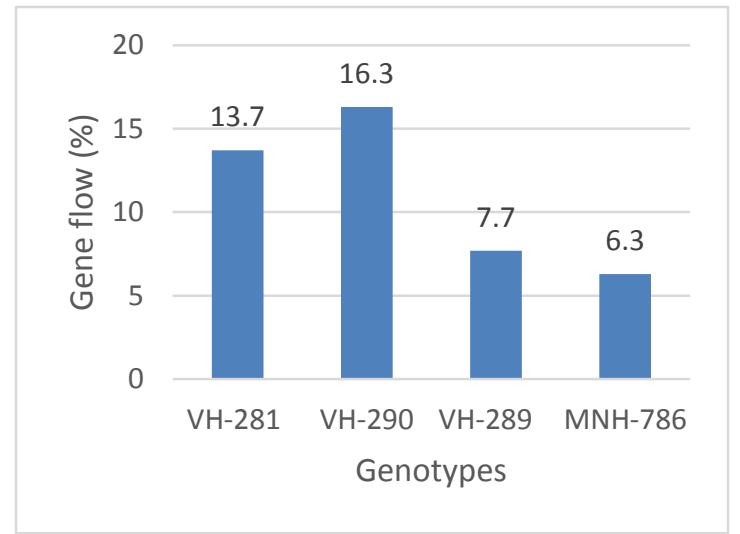

Figure 5. Percent gene flow in various genotypes in insecticide sprayed field

\section{Discussion}

Honey bees are the most important pollinators in cotton that visit the flowers of the same plant or randomly the flowers of several other plants which ultimately result in intra and interspecific gene flow. Pollinator population is affected by various factors depending upon the type and stage of the crop as well as natural environmental conditions. Present studies demonstrated that pollinator population was more in control or unsprayed field compared with the insecticide treated or sprayed plots. Honey bee reduction percentage in insecticide treated plot was upto $92 \%$, which was either due to direct exposure to toxic effect of insecticides or by feeding on toxic nectars collected by bees. Acute, lethal and sublethal effect of insecticides have already been reported by [ 3 ,
9]. The effect differed with respect to the class/ group of pesticides due to difference in mode of action [4].

Among cultivars availability of pollinators and gene flow were more on VH-290 compared with other genotypes. It might be due to size of the flower as well as pollen color, its viability and stickiness to the body, nectar secreting sites and pollen collecting legs of the bees [10-12]. Present study results demonstrated that $\mathrm{VH}-290$ had large flowers with 6 petals and yellow pollen color making it more attractive (Fig. 6) which lures the insects/pollinators more than the creamy pollen genotypes with small flowers. Several other researchers also reported that the pollinators were preferably attracted towards large flowers with yellow pollen color [13]. According to McGregor [14] nectar is 
secreted by floral and extra floral nectarines. The extra floral nectarines exist on outer parts of the flower either bracteoles or sub bracteoles. All the nectar secreting sites make a flower more attractive for honey bees or the pollinators [11, 12]. Large flowers of $\mathrm{VH}$ 290 possibly had more nectar secreting sites than rest of the cultivars and hence more attractive for foraging honey bees.

Pollinators particularly honey bee had a great significance from an agricultural point of view. Although honey bees are reported to increase the crop productivity by ensuring maximum pollination yet these are also a key source of pollen mediated gene flow from one genotype to others. Pollen mediated gene flow from transgenic to non-transgenic crops could be a severe threat to biodiversity, seed production practices and could develop field evolved resistance in lepidopterous larvae against transgenic crops. This type of gene flow from GM to non-GM counterparts and weedy relatives has been one of the major concerns of ecologists/researchers in
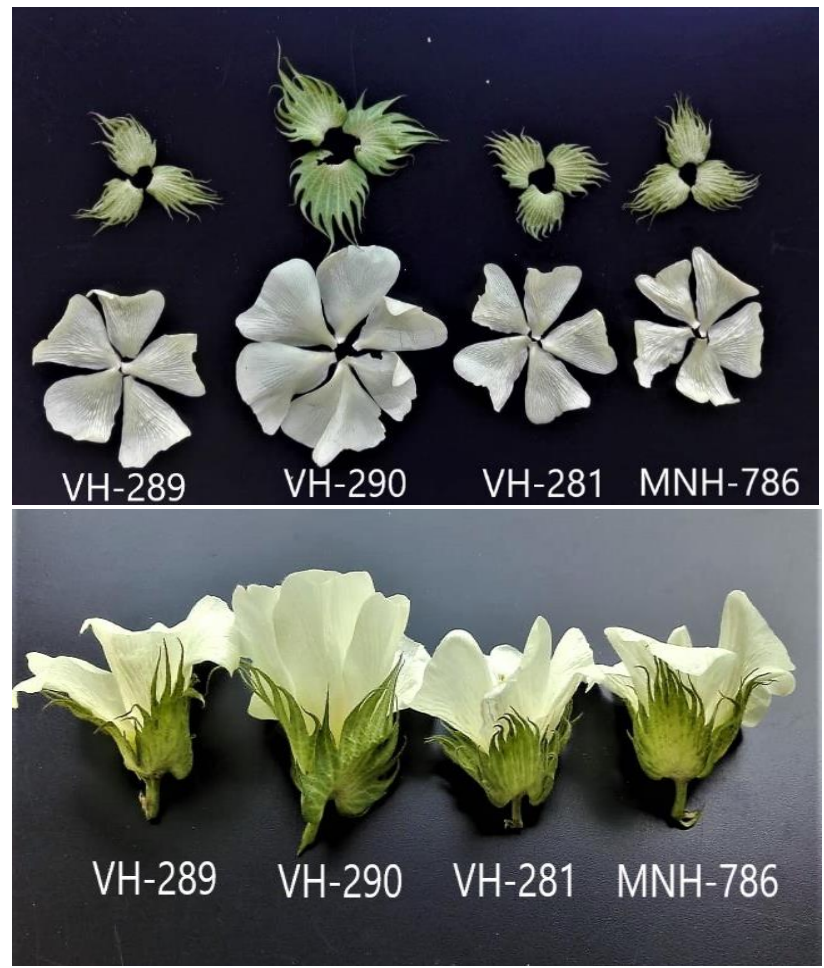

commercialization of transgenic crops, therefore seed production blocks of non Bt. crops should be planted in containment or in complete isolation to avoid the danger of contamination. Although the isolation distance is affected by several factors and varies from location to lactation yet Zhang [15] suggested an isolation distance of at least $20 \mathrm{~m}$ between the two crops to minimize the chances of gene flow from Bt. to non-Bt crops.

Regression analysis validated the toxicity of insecticide on honeybee and showed that the gene flow was almost doubled in pesticide untreated plots than that of pesticide treated plots. Per unit increase in honeybee population also triggered more amount of gene flow in untreated plots than in treated plots. As pollen mediated gene flow in cotton is directly related to pollinator population therefore reduced population of honeybees under toxic effects of pesticide also resulted in reduced gene flow.
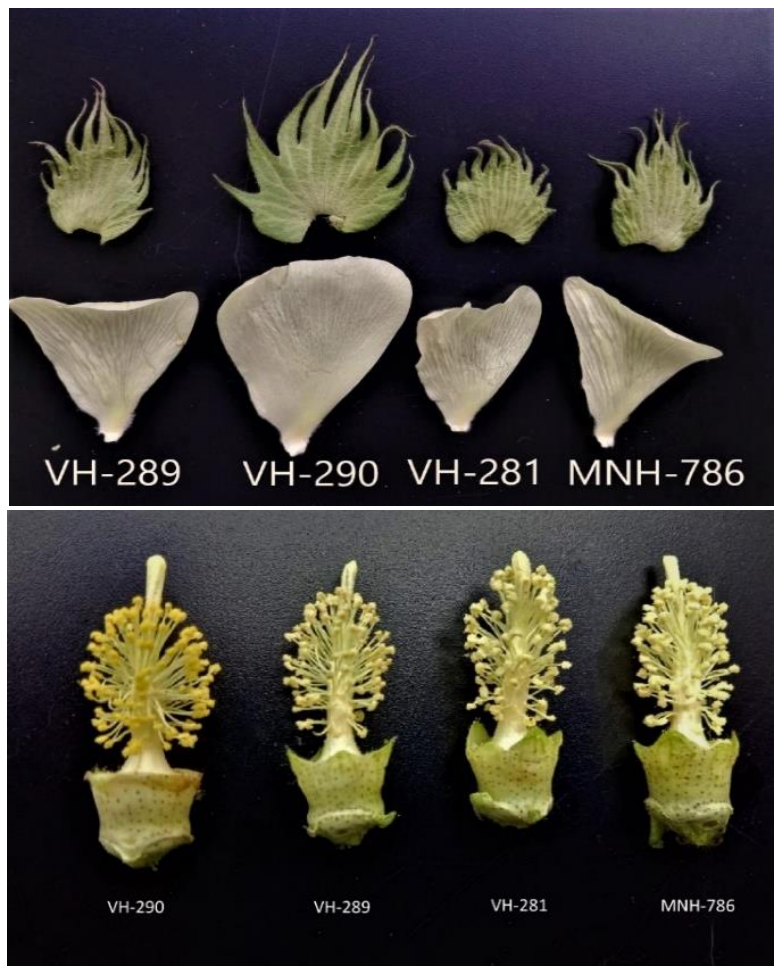

Figure 6. Comparison of floral morphology of different genotypes 


\section{Conclusion}

Floral morphology could play a significant role in attracting honey bee pollinators. It should be kept in consideration while planting non Bt refugia; because there will be chance of pollen mediated gene flow in cotton through honeybees which could contaminate the seed production plots. Therefore, it is suggested that an optimum isolation distance should be maintained for pure seed production.

\section{Authors' contributions}

Conceived and designed the experiments: $\mathrm{S}$ Ahmad; Performed the experiments: S Ahmad, G Ahmad \& MA Sadiq; Analyzed the data: M R Shahid, AL Tipu \& M Shahid; Contributed reagents/ materials/ analysis tools: W Nazeer, A Jabbar, M Akram \& MA Saleem; Wrote the paper: ZU Zia.

\section{References}

1. Deguine, JP, Ferron P \& Russell D (208) Sustainable pest management for cotton production. A review. Agron Sus Devept 28(1): 113-137.

2. Relyea RA (2005) The impact of insecticides and herbicides on the biodiversity and productivity of aquatic communities. Eco Appl 15(2): 618-627.

3. Stenersen J (2004) Chemical Pesticides Mode Of Action And Toxicology. CRC press.

4. Pisa LW (2015) Effects of neonicotinoids and fipronil on non-target invertebrates. Environ Sci Pol Res 22(1): 68-102.

5. ISAAA (2017) Global Status of Commercialized Biotech/GM Crops in 2017: Biotech Crop Adoption Surges as Economic Benefits Accumulate in 22 Years. ISAAA Brief 53.

6. Crane E \& Walker P (1983) The Impact of Pest Management on Bees and
Pollination. Tropical Development and Research Institute.

7. Corbet SA, Williams IH \& Osborne JL (1991) Bees and the pollination of crops and wild flowers: changes in the European Community. Review commissioned by Scientific and Technical Options Assessment, . European Parliament.

8. Jin L (2015) Large-scale test of the natural refuge strategy for delaying insect resistance to transgenic Bt crops. Nature Biot 33(2): 169-174.

9. Rortais A (2005) Modes of honeybees exposure to systemic insecticides: estimated amounts of contaminated pollen and nectar consumed by different categories of bees. Apidol 36(1): 71-83.

10. Eckhart VM (1991) The effects of floral display on pollinator visitation vary among populations ofPhacelia linearis (Hydrophyllaceae). Evol Eco 5(4): 370384.

11. Prasifka JR (2018) Using Nectar-Related Traits to Enhance Crop-Pollinator Interactions. Frontiers in Pl Sci 9: 812812.

12. Rhodes J (2002) Cotton pollination by honeybees. Aust J Exp Agr 42(4): 513518.

13. Niesenbaum RA, Patselas MG \& Weiner SD (1999) Does flower color change in Aster vimineus cue pollinators? The American Midland Naturalist 141(1): 59-68.

14. McGregor SE (1976) Insect pollination of cultivated crop plants. Agricultural Research Service, US Department of Agriculture Washington, DC Vol. 496.

15. Zhang BH (2005) Measuring gene flow in the cultivation of transgenic cotton (Gossypium hirsutum L.). Mol Biot 31(1): 11-20. 